\section{ECONOMICS}

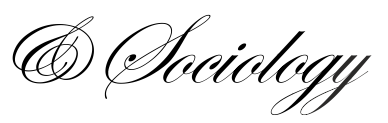

Baranowski, M., \& Jabkowski, P. (2021). Basic income support in Europe: A cross-national analysis based on the European Social Survey Round 8. Economics and Sociology, 14(2), 167-183. doi:10.14254/2071-789X.2021/14-2/9

\title{
BASIC INCOME SUPPORT IN EUROPE: A CROSS-NATIONAL ANALYSIS BASED ON THE EUROPEAN SOCIAL SURVEY ROUND 8
}

\author{
Mariusz Baranowski \\ Adam Mickiewicz University, \\ Poznañ, Poland \\ E-mail: \\ marius:baranowski@amu.edu.pl \\ ORCID 0000-0001-6755-9368 \\ Piotr Jabkowski \\ Adam Mickiewicz University, \\ Poznań, Poland \\ E-mail: \\ piotr.jabkowski@amu.edu.pl \\ ORCID 0000-0002-8650-9558
}

Received: June, 2020

1st Revision: March, 2021

Accepted: May, 2021

DOI: $10.14254 / 2071-$

789X.2021/14-2/9

JEL Classification: I31, I38, J18, J38

\begin{abstract}
In recent years, the issue of unconditional basic income has become both an element of a broad discussion among theoreticians and practitioners responsible for public policy and a basis for the experiments aimed at investigating social and economic consequences of introducing this programme; however, there is a lack of empirical analyses focused on public attitudes towards basic income. Based on the data from the European Social Survey Round 8 ( $\mathrm{n}=41,830)$, we examined the level of support for introducing basic income and identified its individual-level determinants in 22 European countries. Our analysis focused on the systematic differences (both in the level of support for basic income and the strength of the impact of sociopolitical factors) between particular countries and different European regions, namely Western, Southern, Northern and Central-Eastern states. The results confirm that the support for basic income varies according to (a) the region of Europe as well as (b) the key role of the socioeconomic position of the individual.
\end{abstract}

Keywords: unconditional basic income, basic income attitudes, cross-national analysis, European Socio-economic Classification, European Social Survey

\section{Introduction}

\section{Background}

Unconditional basic income (hereafter denoted as UBI), also known as universal basic income, basic income guarantee, citizen income or citizen dividend (Arthur, 2016), is a proposal for a specific monetary benefit under the social policy system. It is a specific proposal because it breaks with the idea of conditionality, which dominates in current social security systems and is often identified by a means test or work requirement (Van Parijs, 1992b). Apart from the monetary and the unconditional character of UBI, this postulate also includes periodicity (regularity of - usually monthly - payments), individuality (to be paid to 
an individual and not to a household) and universality (addressed to all citizens or residents) (Basic Income Earth Network, 2017).

In the purely cognitive dimension, the concept of UBI is one of the responses to the crisis in the welfare state, which has been discussed since the 1970s (Alber, 1988; Avi-Yonah, 2000; Moran, 1988; Offe, 1984; Shapiro \& Shapiro, 1990). Although the historical roots of this idea can already be found in the Utopian socialism of Charles Fourier and in the works of the Belgian thinker Joseph Charlier (cf. Cunliffe \& Erreygers, 2001), it was not until the 1970s that the proposal of unconditional financial benefits to live above the poverty line was tested in the United States (Widerquist \& Sheahen, 2012) and Canada (Forget, 2012). Regardless of the definition and option of basic income (the proponents of this option differ considerably in substantive and technical details), it is often discussed in a broad human rights context (cf. Alston, 2018; Klein, 2018; Piachaud, 2018; Spicker, 2019; Yang, 2018).

The extensive literature on UBI has contributed to better insight into how different individuals can benefit from the introduction of UBI. Many studies on the topic have focused on gender, age, political orientation or class position. Although the basic income scheme is addressed to all citizens and residents regardless of their gender, age or any other sociopolitical characteristics, it can be assumed that individual-level factors influence the support of the scheme. Regarding the gender issue in the context of the UBI programme, according to one of the leading proponents of this proposal for social security reform, Philippe Van Parijs, the matter is clear and obvious. He assumed - purely theoretically - that 'both in terms of direct impact on the inter-individual distribution of income and the longer-term impact on job options, a UBI is therefore bound to benefit women far more than men. Some of them, no doubt, will use the greater material freedom UBI provides to reduce their paid working time and thereby lighten the "double shift" at certain periods of their lives. [...] It provides a modest but secure basis on which the more vulnerable can stand, as marriages collapse or administrative discretion is misused' (Van Parijs, 2000, p. 6). This point of view is not isolated among UBI supporters in particular (Alstott, 2001; Sutherland, 2018; Zelleke, 2008), but there are also more cautious and subdued (Baker, 2008; Elgarte, 2008; Robeyns, 2001) or opposing positions (Bergmann, 2008; Husson, 2006). Concerning the age effect on UBI support, arguments formulated by the theorists of basic income consider young people in particular as potential supporters as they are more exposed to a discontinuity in employment as well as older people as they receive low pension benefits (O'Reilley, Moyart, Nazio, \& Smith, 2017; Standing, 2017).

Regarding the potential impact of political orientation on UBI support, one might note that this idea is promoted by researchers with different political and economic orientations (Juliet Rhys-Williams developed the Negative Income Tax Concept in the 1940s, but two decades later, it was promoted by Milton Friedman [1962]); however, it is more often identified as a left-wing option (Van Parijs, 1992a), though the problem of including UBI in political narratives is highly fluid and complicated (Howard, 2005; Parolin \& Sioland, 2020). Moreover, one of the main determinants of UBI support is the class position of the individual determined by ownership relations, control of work processes and the phenomenon of consumption. Because disputes about class position and its determinants are beyond the scope of this article (Cerami, 2008), we will assume that the socio-structural position of the individual influences the support or lack of it in relation to UBI. Working-class representatives whose position in the labour market is unstable are interested in supporting UBI along with extensive welfare state systems and high minimum wages (Standing, 2017). 


\section{Aims of the paper}

There is a considerable gap between a rich theoretical consideration of the UBI schemes and a limited number of various empirical studies (field experiments, see Haushofer \& Shapiro, 2013; Schjoedt, 2016; Standing, 2013; financial simulations, see Arcarons, Pañella, \& Mèlich, 2014; OECD, 2017) with a particular emphasis on the surveys on this topic (Baranowski \& Jabkowski, 2019; Cardone, 2021; Lee, 2018; Roosma \& van Oorschot, 2020; Vlandas, 2021). Thus, there is a clear need for a systematic empirical cross-national analysis to better understand the importance of individual factors for UBI support in different national contexts. Therefore, in this paper, we use the European Social Survey Round 8 to examine the level of UBI support and its determinants in 22 European countries.

The article focuses on four main objectives: (a) a descriptive analysis of cross-national differences in the country-level support for UBI, (b) an exploration of the impact of different individual-level socio-political covariates and demographic factors on basic income support across 22 countries, (c) an analysis of cross-country variation in the strength of individuallevel effects and (d) an examination of differences in the level of support for UBI among European regions and the cross-regional differences in the strength of associations of all individual-level variables. Two guiding research hypotheses have been considered in this study:

Hypothesis 1: Support for basic income varies according to the country's belonging to a European region, i.e. the more economically developed the country (northern and western Europe), the lower the support for the UBI scheme.

Hypothesis 2: The socio-economic position of an individual determines the support for basic income, i.e. the higher the individual's position as measured by the European Socioeconomic Classification (ESeC), the lower the support for the UBI programme.

$\mathrm{ESeC}$ is built on a well-known social class schema, referred to in the social sciences as EGP (Erikson-Goldthorpe-Portocarero). Accordingly, ESeC assumes four main employment positions: (1) employers, (2) self-employed, (3) employees and (4) those involuntarily excluded from paid employment (Rose \& Harrison, 2007, p. 461), which are further specified, for example, by company size. In the context of the second hypothesis, according to supporters of basic income (Van Parijs \& Vanderborght, 2017), in the countries of Northern and Western Europe, the middle and upper classes should have higher support for this programme than in the countries of Central and Eastern or Southern Europe. The latter is explained by the universal model of social policies, which translates into more egalitarian social relations. We should also note the heterogeneity of countries within given regions due to, for example, wealth, the specificity of social institutions and political culture (Ehnts \& Höfgen, 2019; Toporowski, 2019).

\section{Data and methods}

\subsection{The European Social Survey}

These three countries are relatively small and underdeveloped in terms of their geographical size and population, geopolitical importance, market size and aggregate demand, production, investment, export, and technological potential. According to many noneconomic indicators (political stability, democratization, liberalization and institutionalization of society, law, infrastructure development, safety, security, investment, compliance with environmental and social standards, efficiency of the legal system, human rights respect, etc.), as well as economic indicators (purchasing power, rate of economic growth, foreign trade 
balance, current account deficit, public debt, inflation rate, unemployment rate, public expenditure, investments, etc.), they are characterized by a long-term transitional crisis of structural type (Husson, 2019).

The European Social Survey (ESS) constitutes a well-regarded cross-national survey conducted biennially since 2002. The ESS has a strong emphasis on the standardisation of research procedures to enable cross-national comparisons of results (Fitzgerald \& Jowell, 2010). Only strictly national-probabilistic samples are allowed in participating countries, and each national coordinator team is also responsible for producing a sample design that adheres to ESS principles and is suitable for implementation in their countries (Kaminska \& Lynn, 2017). Careful attention is also paid to the questionnaire development process to achieve optimal comparability across countries (for a review, see Fitzgerald, 2015). Interviews are conducted face-to-face by trained interviewers with individuals aged $15+$ living in private households within country borders irrespective of nationality, citizenship, language or legal status. All countries must achieve a minimum effective sample size of 1,500 respondents (or 800 in countries with populations of less than two million) after discounting for design effects (a total number of 41,830 respondents have participated in the ESS 8). Two types of weights are also produced. First, population size weights are used to consider differences in the size of the countries' populations. Second, post-stratification weights (including design weights) are used to account for differences in inclusion probabilities, sampling errors and potential nonresponse errors (see Lynn, Häder, Gabler, \& Laaksonen, 2007). Table 1 provides information on the 22 European countries participating in the $8^{\text {th }}$ round of the ESS.

Table 1. Information on countries participating in the ESS8-2016 and the country-level mean score value of basic income support

\begin{tabular}{|c|c|c|c|c|c|}
\hline Country & Region & $\begin{array}{c}\text { Population size } \\
\text { million }\end{array}$ & $\begin{array}{c}\text { Sample size } \\
\mathrm{N}\end{array}$ & $\begin{array}{c}\text { Item non-response }{ }^{(2)} \\
\%\end{array}$ & $\begin{array}{c}\text { Basic income support }{ }^{(3)} \\
\%\end{array}$ \\
\hline Austria & $\mathrm{W}$ & 8.70 & 2,010 & 6.7 & 49.3 \\
\hline Belgium & $\mathrm{W}$ & 11.31 & 1,766 & 1.3 & 59.5 \\
\hline Czechia & $\mathrm{CEE}$ & 10.55 & 2,269 & 9.0 & 50.2 \\
\hline Estonia & CEE & 1.32 & 2,019 & 4.4 & 45.6 \\
\hline Finland & $\mathrm{N}$ & 5.49 & 1,925 & 3.9 & 57.8 \\
\hline France & $\mathrm{W}$ & 66.73 & 2,070 & 4.4 & 49.4 \\
\hline Germany & $\mathrm{W}$ & 82.18 & 2,852 & 3.0 & 45.8 \\
\hline Hungary & CEE & 9.83 & 1,614 & 10.5 & 69.9 \\
\hline Iceland & $\mathrm{N}$ & 0.33 & 880 & 7.3 & 49.0 \\
\hline Ireland & $\mathrm{W}$ & 4.73 & 2,757 & 8.7 & 58.7 \\
\hline Italy & $\mathrm{S}$ & 60.66 & 2,626 & 13.6 & 58.5 \\
\hline Lithuania & CEE & 2.89 & 2,122 & 16.8 & 79.1 \\
\hline Netherlands & $\mathrm{W}$ & 16.78 & 1,681 & 4.8 & 49.9 \\
\hline Norway & $\mathrm{N}$ & 5.21 & 1,545 & 4.0 & 33.1 \\
\hline Poland & CEE & 37.97 & 1,694 & 14.6 & 58.7 \\
\hline Portugal & $\mathrm{S}$ & 10.34 & 1,270 & 6.3 & 58.5 \\
\hline Russian Federation & CEE & $143.67^{(4)}$ & 2,430 & 19.3 & 73.4 \\
\hline Slovenia & $\mathrm{CEE}$ & 2.06 & 1,307 & 7.8 & 67.9 \\
\hline Spain & $\mathrm{S}$ & 46.44 & 1,958 & 11.4 & 50.5 \\
\hline Sweden & $\mathrm{N}$ & 9.85 & 1,551 & 7.2 & 40.6 \\
\hline Switzerland & $\mathrm{W}$ & 8.33 & 1,525 & 5.3 & 35.9 \\
\hline United Kingdom & $\mathrm{W}$ & 65.38 & 1,959 & 5.6 & 53.8 \\
\hline \multicolumn{6}{|c|}{$\begin{array}{l}\text { Notes: Post-stratification weights (including design weights) have been applied for country-level estimation of } \\
\text { basic income support; Region: CEE: Central and Eastern Europe, N: Northern Europe, S: Southern Europe, } \\
\text { W: Western Europe; (1) Source: Eurostat data for } 2016 \text { (population on 1 } 1^{\text {st }} \text { of January); (2) Non-prompted options: } \\
\text { "Don't know" \& "Refusal"; (3) Coding: 0: against / strongly against, 1: in favour / strongly in favour; (4) Data } \\
\text { available for } 2014 \text {. } \\
\text { Source: own elaboration based on ESS8 (2016). }\end{array}$} \\
\hline
\end{tabular}


Each round of the ESS focuses on a range of different themes that are largely the same in each round (core modules) and on two key social themes (rotating modules), which are sometimes repeated in later rounds of the ESS. One of the rotating modules included in the ESS 8 is 'Welfare Attitudes in a Changing Europe' (for details, see ESS, 2016a). Note that the rotating module on welfare has not been repeated in the $9^{\text {th }}$ Round of the ESS (2018), i.e. the analysis presented in this paper is based on the most recent available ESS data on this topic.

\subsection{Measures}

\subsubsection{Dependent variable}

Basic income support. The definition of basic income in the ESS survey comprises six elements (question E36, card 54 from ESS questionnaire): (1) The government pays everyone a monthly income to cover essential living costs; (2) It replaces many other social benefits; (3) The purpose is to guarantee everyone a minimum standard of living; (4) Everyone receives the same amount regardless of whether or not they are working; (5) People also keep (in the sense of 'continue receiving') the money they earn from work or other sources; and (6) This scheme is paid for by taxes (ESS, 2016b). Such an understanding of UBI is part of a broadly understood project to reform the social security system but differs from the definitions adopted in other studies (e.g. Ipsos, Dalia Research, cf. Baranowski \& Jabkowski, 2019). Particularly noteworthy is the second point, referring to the replacement of existing welfare state institutions (cf. Lee, 2018, p. 7), which in the case of generous social security systems (especially in Scandinavian countries) may result in ambivalent attitudes.

After presenting the idea of a basic income scheme, respondents were asked whether they 'would be against or in favour of having this scheme in [country]?' Respondents could use one of the following answer options: 'strongly against', 'against', 'in favour' and 'strongly in favour'. In our analysis, the 4-point response scale was dichotomised to 1 ('in favour' / 'strongly in favour') and 0 ('against' / 'strongly against'). The non-prompted options of 'don't know' and 'refusal' were coded as missing to avoid overlap with scepticism toward basic income; however, because the size of item-nonresponse varies significantly across countries (from 1.3\% in Belgium to $19.3 \%$ in Russian Federation; for details, see Table 1.), we decided to include missing responses in a particular country as a control variable in the regression analyses. A supplementary online file containing syntax with SPSS commands for creating all variables was implemented in the analysis presented in this paper.

\subsubsection{Independent variables}

The European Socio-Economic Classification. The European Socio-Economic Classification (ESeC) was used, which 'aims to differentiate positions within labour markets and production units in terms of their typical "employment relations" (Harrison \& Rose, 2006 , p. 4). The 10-part classification for analysis purposes was transformed into three categories: lower class, medium class and higher class (cf. Rose \& Harrison, 2007, pp. 470471). In the supplementary materials, there is a syntax file for creating 'ESeC Classification' adapted to ESS round 8 variables.

Left-right political orientation. This was measured by asking respondents to position themselves along a Left-Right 11-point scale using the following question: 'In politics, people sometimes talk of "left" and "right". Using this card, where would you place yourself on this scale, where 0 means the left and 10 means the right?' Prior to including 'left-right political 
orientation' in a regression analysis, the original scale points were standardised by calculating z-scores across all countries.

Perceiving consequences of social benefits. Three correlated latent variables were used to evaluate people's attitudes toward the consequences of social benefits. Namely: (a) the perception of 'social consequences' measured by two questions: 'Using this card, please tell me to what extent you agree or disagree that social benefits and services in [country]: [1] ... prevent widespread poverty?; [2] ... lead to a more equal society?'; (b) the perception of 'moral consequences' measured by two other questions: 'Using this card, please tell me what extent do you agree or disagree that social benefits and services in [country]: [1] ... make people lazy?; [2] ... make people less willing to care for one another?'; and (c) the perception of 'economic consequences' measured by two more questions: 'Using this card, please tell me to what extent you agree or disagree that social benefits and services in [country]: [1] ... place too great a strain on the economy?; [2] ... cost businesses too much in taxes and charges?' With regard to these six questions, the same 5-point response options were used: 1 (Disagree strongly), 2 (Disagree), 3 (Neither agree nor disagree), 4 (Agree) and 5 (Agree strongly).

For the cross-country analysis, a Multi-Group Structural Equation Modelling (MGSEM) approach was employed (Byrne, 2016) to construct the latent variables and to evaluate the quality of such scales. This procedure provides significant advantages over constructing scales simply by calculating the sum or mean of its item scores because it is equipped with tools for equivalence-testing, i.e. determining whether construct-based cross-country comparisons are legitimate in the first place. The final measurement model of each latent construct assumes cross-country configural as well as metric equivalence restrictions. Configural equivalence means that the factor structure is the same in all 22 countries, while metric equivalence adds a further assumption that the factor loadings are equal (which translates into a direct comparability of regression coefficients). In addition, the scalar equivalence would further postulate equal intercepts, which would translate into direct crossnational comparability of scale averages. In the supplementary materials, there is detailed information on the MG-SEM model fit statistics and a syntax file for creating each of the latent variables. The MG-SEM analyses confirmed cross-country configural and metric equivalence; however, given that the measurement model under consideration turned out not to comply with the structures of scalar equivalence, it only allows for comparing the regression coefficients across 22 countries (i.e. it enabled cross-national comparisons of the direction and strength of the associations of each variable with the propensity to support the introduction of a basic income scheme).

Demographics. We have created two demographic variables, i.e. gender and age. Gender was indicated as 0 (female) and 1 (male), while age was expressed in 10-year intervals covering people aged 15-24, 25-34, 35-44, 45-54, 55-64 and 65+ respectively. We also included the age square variable to evaluate the non-linear effect of age on basic income support.

By the term European regions, we mean groups of European countries. In our analysis, we have distinguished between Central and Eastern European states (i.e. postcommunist countries: Czechia, Estonia, Hungary, Lithuania, Poland, Russian Federation and Slovenia), Southern European countries (Italy, Portugal and Spain), Northern European states (Finland, Iceland, Norway and Sweden) and Western European countries (Austria, Belgium, France, Germany, Ireland, Netherlands, Switzerland and Great Britain). This distinction was made because there is ample evidence that European attitudes toward welfare systems are associated with welfare regimes represented by clusters of countries covering different European regions (for further discussion see Roosma, van Oorschot, \& Gelissen, 2014; Cook, 2013; Rhodes, 2014; Arts \& Gelissen, 2002). Note that Israel is the only non-European 
country involved in the ESS round 8; hence, it was excluded from the analysis presented in this paper.

\subsubsection{Data analysis}

We have used a logistic regression analysis to assess the direction and strength of the associations of all individual-level effects (i.e. independent variables) with respondents' propensity to support the basic income scheme; however, we began with a descriptive analysis of cross-national differences in the country-level support for the basic income scheme. We then ran a series of logistic regression models to predict the probability of reporting support toward UBI, which is conditional based on the characteristics of respondents (level-1) and countries (level-2). Let us denote by $U B I_{i j}$ an outcome dichotomous variable, where $E\left(U B I_{i j}=1\right)=\pi_{i j}$ is the probability of reporting support for UBI by a respondent $i$ in a country $j$. For an outcome variable, we use a logit link function (based on the natural logarithm), where the logit coefficient $\eta_{i j}=\log \left(\frac{\pi_{i j}}{1-\pi_{i j}}\right)$ is the log of the odds of the event $U B I_{i j}=1$ as opposed to $U B I_{i j}=0$. We began with Model 1 (fixed effects model), which includes the set of all level-1 factors and covariates of UBI, i.e. European Socioeconomic Standard, social consequences of social benefits, moral consequences of social benefits, economic consequences of social benefits, political orientation, gender, age, a square of age and the level-2 variable of UBI item non-response rate. Because our goal was to assess the overall association of all individual-level effects with basic income support across all countries, the data were weighted by total weights, i.e. by the linear combination of population size weights and poststratification weights. Model 2 (fixed and random effects model) was an extension of Model 1 in which - separately for each level-1 variable - we let the regression coefficient vary across countries. Finally, we examined differences in the level of support for the basic income scheme between European regions and the cross-regional differences in the strength of associations of all independent variables with basic income support. Model 3a (main effects) includes the European region as the only nominal variable (the Western European states constitute the reference category for this analysis), and Model $3 \mathrm{~b}$ (main effects and interactions) adds the interaction of European regions with all independent variables. For both Model $3 a$ and Model $3 b$, the data were weighted by total weight (i.e. population size weight combined with poststratification weight).

\section{Results}

\subsubsection{Cross-country differences in a basic income support}

In line with several recent theoretical and empirical studies on UBI (cf. Baranowski \& Jabkowski, 2019; Lee, 2018; Meuleman et al., 2018; Rossetti, Roosma, Laenen, \& Abts, 2020; Taylor-Gooby \& Leruth, 2018), we find that the overall support for basic income varies widely in the European countries participating in the 8th round of the ESS project. For example, national-level support for the basic income scheme ranged from $33.1 \%$ in Norway to $79.9 \%$ in Lithuania (see Table 1). In half of the considered countries (namely: Belgium, Finland, Hungary, Ireland, Italy, Lithuania, Poland, Portugal, Russian Federation, Slovenia and the United Kingdom), the majority of the population supports the introduction of basic income (i.e. the fraction of population supporting its introduction is significantly higher than $50 \%$ at the 0.05 significance level), while in the second half (namely: Austria, Czechia, Estonia, France, Germany, Iceland, Netherland, Norway, Spain, Sweden and Switzerland), the 
level of support is significantly less or at most not significantly different from $50 \%$. Most notably, these wide cross-country differences in the level of support for the basic income scheme show the need for searching for patterns of cross-country and cross-European similarities or dissimilarities, both in the level of support for basic income and in the association of socio-political and demographic factors with a propensity to support the introduction of the basic income scheme.

\subsubsection{Individual-level effects on basic income support}

Table 2 presents the impact of the socio-political and demographic variables on basic income support across all 22 European countries participating in the ESS round 8. The analysis is based on a logistic regression, where all individual-level factors and covariates are included as independent variables.

Table 2. Impact of the socio-political and demographic variables on basic income support: logistic regression (Model 1)

\begin{tabular}{ll}
\hline \multicolumn{1}{c}{ Socio-political covariates and demographics } & $\hat{\beta}(\mathrm{SE})$ \\
\hline European Socioeconomic Standard ESeC & $-.089(.014)^{* * *}$ \\
\hline Social consequences of social benefits & $.068(.012)^{* * * *}$ \\
\hline Moral consequences of social benefits & $-.144(.017)^{* * *}$ \\
\hline Economic consequences of social benefits & $-.030(.021)^{\text {n.s. }}$ \\
\hline Political orientation (left - right) & $-.103(.012)^{* * *}$ \\
\hline Gender: male (vs female) & $-.029(.023)^{\text {n.s. }}$ \\
\hline Age & $-.250(.031)^{* * *}$ \\
\hline Age squared & $.023(.004)^{* * * *}$ \\
\hline Control variable: item non-response & $3.892(.214)^{* * *}$ \\
\hline
\end{tabular}

Notes: Population size weights combined with post-stratification weights have been applied; ${ }^{* * *} \mathrm{p}<0.01$; ${ }^{\text {n.s. }}$ not significant; $\hat{\beta}=$ estimates of regression coefficients; $\mathrm{SE}=$ standard error of $\hat{\beta}$.

Source: own elaboration based on ESS8 (2016).

As shown in Table 2, six variables are significant predictors of basic income support, while two are not (namely gender and perceiving economic consequences of social benefits). Notably, the European Socioeconomic Standard classification significantly differentiates the propensity to support a basic income. The relation is negative, i.e. the higher the respondent is located in a social class hierarchy, the lower level of basic income support he or she demonstrates. Moreover, the estimates of logistic regression coefficients indicate that the individuals who perceive more positive consequences of social benefits have a significantly higher propensity to support UBI. In comparison, those who perceive more negative moral consequences of social benefits have a lower propensity to support the introduction of basic income.

Moreover, individuals who place themselves nearer to the right side of the political spectrum are significantly less likely to support the introduction of a basic income scheme. The level of support is also negatively associated with age (i.e. the older the respondents, the lower level of support) but positively associated with age squared. Note that a positive effect of age and a negative effect of age squared means that as people age, the impact of age on the propensity to support UBI is weaker. The question is still open regarding whether this general pattern of associations of socio-political and demographic variables with basic income support observed across all 22 European countries participating in the $8^{\text {th }}$ round of the ESS would also be observed in each country separately. 


\subsubsection{Cross-country differences in the strength of individual-level effects of basic income support}

To investigate cross-country differences in the strength and the direction of the impact of the socio-political and demographic variables on basic income support, we conducted a series of logistic regression analyses in which both the intercepts as well as regression coefficients were allowed to vary across all 22 European countries participating in the ESS8 (Model 2). Figure 1 visualises the cross-country differences in the average level of support for UBI (vertical axis; ranging from 0 to 1 ) respectively for each factor and covariate, i.e. (a) ESeC classification, (b) social, (c) moral and (d) economic consequences of social benefits, (e) political orientation, (f) gender and (g) age. Some effects are more consistent across countries than others. Moreover, cross-country differences in the associations lead to a different conclusion regarding the strength of the impact and its direction.

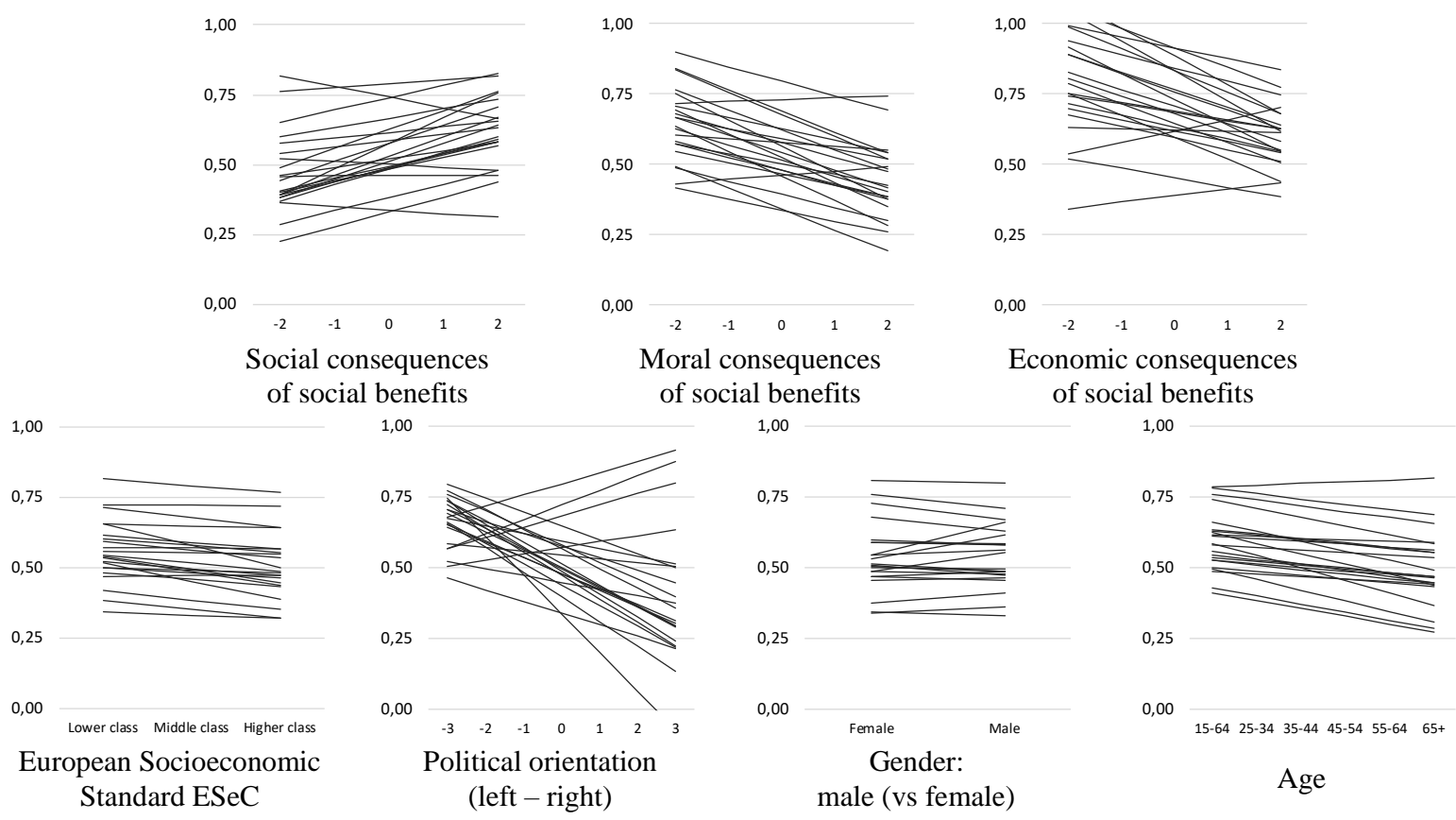

Figure 1. Cross-country differences in the associations of the socio-political and demographic variables (x-axis) with average level of basic income support (y-axis) in 22 countries (Model 2)

Source: own elaboration based on ESS8 (2016).

The associations of ESeC with basic income support are consistent across all 22 countries in terms of the direction (the higher the social class position of the individual, the lower the support); however, there are considerable cross-country differences in the significance of this association. The strength of associations is negligible in most countries because only five of all 22 have significant associations. The associations of the social, moral and economic consequences of social benefits with basic income support are generally consistent with only a few exceptions. For example, in the majority of countries, the more positive the social consequences of social benefits respondents perceive, the higher the level of support for basic income, though this is not true in three countries (namely: Spain, Norway and Russian Federation), where a reverse direction is observed. Moral and economic consequences of social benefits are negatively associated with basic income support (except for Estonia and Russian Federation), but these associations are negligible in 12 and 16 
countries, respectively. In most countries, individuals with a left-leaning political orientation are more likely to support the introduction of a basic income scheme, which is not true in four CEE countries (namely: Hungary, Lithuania, Poland and Russian Federation), where a rightleaning political orientation favours more positive feelings toward a basic income scheme. Finally, the association of gender with basic income support is not significant in 15 countries, and the association of age is not significant in 10 countries.

\subsubsection{Differences in the strength of effects between European regions}

Finally, we also conducted a series of analyses to examine any systematic differences between countries in different European regions. Table 3 presents the results of the logistic regression models with the main effect (Model 3a) and the interaction effect (Model 3b) of European regions (Central and Eastern, Southern and Northern European countries that participated in the ESS8, with Western European countries set up as a reference category) with the socio-political and demographic variables. As shown in Table 3, support for basic income is significantly higher in Central and Eastern European countries. The Odds Ratio [hereafter denoted as OR] is equal to $1.27,95 \% \mathrm{CI}$ of the OR range from 1.19 to 1.35 compared to the overall support observed in Western European states, while in Northern Europe, basic income support is significantly lower $(\mathrm{OR}=0.79,95 \% \mathrm{CI}$ of $\mathrm{OR}$ range from 0.75 to 0.84) compared to Western Europe. Southern European states (OR=0.97, 95\%CI of OR range from 0.90 to 1.04 ) do not significantly differ from Western European states.

It should be noted as well that the interaction effect model indicates the extent to which the particular effects (variables) in the model in Central and Eastern, Southern and Northern European countries differ from the effect that can be observed in the reference category, i.e. Western European countries. Hence, the interaction effects must be compared with the main effect of a particular variable, reflecting their association with basic income support in Western European Countries. For example, suppose the overall estimate of the regression coefficient for any variable of interest is positive and significant. In this case, the negative interaction indicates the weaker effect of such a variable in a particular region than the strength of the effect in Western European countries. Similarly, if the overall regression coefficient is negative and significant, a negative interaction strengthens the already 'existing' negative effect, and a positive interaction weakens it. Finally, if the regression coefficient is not significant (which means that it is close to zero), a positive interaction may be interpreted in terms of a positive effect. Similarly, a negative interaction may be interpreted in terms of the negative effect of a particular variable in the region of interest.

Considering how the interaction effect model is affected, one can conclude that the negative and significant impact of $\mathrm{ESeC}$ on basic income support and a significantly negative estimate of the regression coefficient in Central and Eastern European countries indicates that those belonging to the higher class have a more negative effect on support for UBI than in Western Europe. On the other hand, the strength of the effect of ESeC in Southern and Northern European states does not differ significantly from the strength of the effect in Western European countries. Moreover, the effect of the social consequences of social benefits is generally weaker in Southern Europe than in Western Europe, while in Central and Eastern European countries, the effect of the social consequences of social benefits is stronger than in Western European countries. Economic consequences of social benefits are negatively associated with basic income support only in Northern European countries, while the negative effect of gender (lower support for basic income among males) is only significant in Central and Eastern Europe. Moreover, the effect of political orientation is weaker in all regions of Europe compared to the strength of the effect in Western Europe. There is no significant 
difference in the strength of effects between European regions for the moral consequences of social benefits, age or age squared.

Table 3. Impact of interactions of European regions with the socio-political and demographic variables on basic income support: logistic regression (Model 3a: main effects \& Model 3b: interactions)

\begin{tabular}{|c|c|}
\hline Main effects \& interactions & $\hat{\beta}(\mathrm{SE})$ \\
\hline \multicolumn{2}{|l|}{ Model $3 a$ (main effects): } \\
\hline \multicolumn{2}{|l|}{ Region } \\
\hline Central \& Eastern Europe & $.236(.032)^{* * *}$ \\
\hline Southern Europe & $-.031(.037)^{\text {n.s. }}$ \\
\hline Northern Europe & $-.233(.031)^{* * * *}$ \\
\hline Control variable: item non-response & $4.810(.312)^{* * *}$ \\
\hline \multicolumn{2}{|l|}{ Model $3 b$ (interactions): } \\
\hline European Socioeconomic Standard ESeC & $-.099(.022)^{* * * *}$ \\
\hline Central \& Eastern Europe & $-.080(.035)^{*}$ \\
\hline Southern Europe & $-.013(.049)^{\text {n.s. }}$ \\
\hline Northern Europe & $-.036(.041)^{\text {n.s. }}$ \\
\hline Social consequences of social benefits & $.159(.022)^{* * * *}$ \\
\hline Central \& Eastern Europe & $.059(.031)^{*}$ \\
\hline Southern Europe & $-.182(.042)^{* * * *}$ \\
\hline Northern Europe & $-.077(.041)^{\text {n.s. }}$ \\
\hline Moral consequences of social benefits & $-.094(.032)^{* * * *}$ \\
\hline Central \& Eastern Europe & $-.032(.043)^{\text {n.s. }}$ \\
\hline Southern Europe & $.053(.055)^{\text {n.s. }}$ \\
\hline Northern Europe & $.179(.073)^{\text {n.s. }}$ \\
\hline Economic consequences of social benefits & $-.032(.037)^{\text {n.s. }}$ \\
\hline Central \& Eastern Europe & $-.006(.053)^{\text {n.s. }}$ \\
\hline Southern Europe & $-.032(.073)^{\text {n.s. }}$ \\
\hline Northern Europe & $-.305(.081)^{* * * *}$ \\
\hline Political orientation (left - right) & $-.254(.021)^{* * *}$ \\
\hline Central \& Eastern Europe & $.245(.031)^{* * *}$ \\
\hline Southern Europe & $.129(.039)^{* * *}$ \\
\hline Northern Europe & $.112(.038)^{* * *}$ \\
\hline Gender: male (vs female) & $.061(.037)^{\text {n.s. }}$ \\
\hline Central \& Eastern Europe & $-.223(.060)^{* * * *}$ \\
\hline Southern Europe & $.126(.082)^{\text {n.s. }}$ \\
\hline Northern Europe & $-.042(.070)^{\text {n.s. }}$ \\
\hline Age & $-.094(.011)^{\text {n.s. }}$ \\
\hline Central \& Eastern Europe & $-.040(.083)^{\text {n.s. }}$ \\
\hline Southern Europe & $-.201(.117)^{\text {n.s. }}$ \\
\hline Northern Europe & $-.083(.088)^{\text {n.s. }}$ \\
\hline Age squared & $.004(.006)^{\text {n.s. }}$ \\
\hline Central \& Eastern Europe & $.008(.010)^{\mathrm{n} . \mathrm{s}}$ \\
\hline Southern Europe & $.025(.014)^{\mathrm{n} . \mathrm{s}}$ \\
\hline Northern Europe & $.006(.011)^{\mathrm{n} . \mathrm{s}}$ \\
\hline Control variable: item non-response & $3.669(.412)^{* * *}$ \\
\hline
\end{tabular}

Notes: Population size weights combined with post-stratification weights have been applied; ${ }^{* * * *} \mathrm{p}<0.01{ }^{\text {n.s. }}$ not significant; $\hat{\beta}=$ estimates of regression coefficients; $\mathrm{SE}=$ standard error of $\hat{\beta}$.

Source: own elaboration based on ESS8 (2016). 


\section{Conclusion}

Considering the political and economic implications of citizens' attitudes toward national decision-making processes and their impact on supranational structures, such as the EU, this study provides a better understanding of the differences in support (or lack of) for the UBI programme. The importance of issues related to social policy institutions, especially in the context of challenges faced by ageing European societies and changing labour markets and class and political changes taking place, indicates the importance of the search for optimal ways to combat dysfunctional forms of action. Basic income is perceived as a possible antidote to challenges related to the full realisation of social citizenship (Pateman, 2004; Purdy, 1994; Zelleke, 2005), the need to reform the existing institutions of the welfare state (Bergmann, 2004, 2008; Murray, 2008; Van Parijs, 1992a), new requirements of the labour markets (Baranowski, 2021; Clark \& Kavanagh, 1996; Elgarte, 2008) and even the progressive automation of production processes (Arntz, Gregory, \& Zierahn, 2017; Dermont \& Weisstanner, 2020; Hughes, 2014; Lucarelli \& Fumagalli, 2008).

Our results show a significant cross-country difference in the level of support for introducing the basic income scheme, both in terms of European regions and individual socioeconomic positions. To begin with, in terms of UBI support across countries due to sociopolitical and demographic variables (Model 2), we found a link between the class position of respondents and UBI support in all 22 countries. The higher the class position of the individual (measured by $\mathrm{ESeC}$ ), the lower the support for basic income. Regardless of the country, the highest performers in the socio-economic division of labour (i.e., those with a stable position in the labour market with a high degree of autonomy in work activities and high wages) are the most sceptical of the UBI (a similar dependence applies to public attitudes toward welfare state scope and responsibilities [see Svallfors, 2012]). This dependence exists even in the Scandinavian countries, which are characterised by a 'greater social protection and universalistic welfare state' (Lee, 2018, p. 7). Therefore, attitudes toward UBI are class-oriented, although national specificities related to economic wealth, the standard of living and the generosity of social policies cannot be ignored. Our analyses clearly show (except for a few countries described in section 3.1.3) that the social, moral and economic consequences of social benefits are consistent in the context of UBI support. The more positively individuals perceive the social consequences of social benefits, the higher their support for the UBI scheme. The moral and economic consequences of social benefits are negatively correlated with the support for basic income due to the construction of questions in the ESS questionnaire (see section 2.2.2). Interesting results were also obtained based on the political orientation of respondents. In the vast majority of countries, those who identify themselves with the left side of the political spectrum have a higher probability of supporting basic income, except for four CEE countries (namely: Hungary, Lithuania, Poland and Russia). In the latter, right-wing supporters are UBI proponents, which can be explained especially in Hungary and Poland-by the specific combination of a right-wing worldview and the populist-social agenda of the ruling political parties (Fidesz - Hungarian Civic Alliance and Law and Justice in Poland). An important conclusion of our analyses is that UBI support is negatively correlated with age (which provides essential information for civic retirement considerations). In the vast majority of countries (15), the impact of gender on UBI support was insignificant, contrary to theoretical arguments (Bergmann, 2008; Van Parijs, 2000).

Our research also has certain limitations, of which we are fully aware. First, the definition of basic income in the ESS project has a direct impact on the measurement process, especially in the context of the Nordic countries and the assumption that UBI is to replace other social benefits (cf. Lee, 2018, pp. 7-8). The latter is a well-recognised problem and 
relates to any research based on surveys (Svallfors, 2012, pp. 1-24). The division into European regions might be problematic as well because it is not based on universal criteria that are acceptable to researchers, and the regions themselves have a high level of heterogeneity (due to very diverse criteria); however, it is used in studies based on survey data as it allows for identifying differences in attitudes of respondents from different parts of the old continent (Huppert \& So, 2013; Keating, 2009; Lipsmeyer \& Nordstrom, 2003; Roosma $\&$ van Oorschot, 2017). The class structure based on the ESeC model, although refined in the methodological layer, intentionally omits the categories of the unemployed or those more broadly excluded from the labour market (Rose \& Harrison, 2007). When analysing attitudes toward basic income, one should be aware of the level of non-response to the key question (see Table 1), which is an interesting methodological challenge that may result in more advanced analyses. We used it as a control variable (see Tab. 2 and Tab. 3), but we see the potential for a wider use of item non-response to explain the differences in UBI support. The political orientation of the respondents must be treated with caution and reserve as the concepts of left-right are understood differently in different national contexts (e.g. postcommunist countries differ substantially in this dimension from the rest of Europe) and may also be blurred in the sense of overlapping economic and political dimensions (Svallfors, 2012).

Given the whole range of potential limitations of our study, the results obtained are an important contribution to the discussion on attitudes toward basic income based on a highquality survey. The articulated limitations are also an excellent contribution to in-depth future empirical research on the widely discussed basic income scheme, especially regarding the attempt to explain in detail the results obtained at the transnational or regional level.

\section{Acknowledgement}

Supplementary online materials are available in this repository: https://osf.io/t7rhd/. The empirical part of this work was supported by a grant awarded by the National Science Centre, Poland: [grant number 2018/31/B/HS6/00403].

\section{References}

Alber, J. (1988). Is there a crisis of the welfare state? Crossnational evidence from Europe, North America, and Japan. European Sociological Review, 4(3), 181-205. https://doi.org/10.1093/oxfordjournals.esr.a036484

Alston, P. (2018). The right to social insecurity: a human rights perspective on the evolution of Australian welfare policy. Australian Journal of Human Rights, 24(3), 253-275. https://doi.org/10.1080/1323238X.2018.1469221

Alstott, A. L. (2001). Good for Women. In P. Van Parijs (Ed.). What's Wrong with a Free Lunch? (pp. 75-79). Boston: Beacon Press.

Arcarons, J., Pañella, D. R., \& Mèlich, L. T. (2014). Feasibility of financing a basic income. Basic Income Studies, 9(1-2), 79-93. doi:https://doi.org/10.1515/bis-2014-0005

Arntz, M., Gregory, T., \& Zierahn, U. (2017). Revisiting the risk of automation. Economics Letters, 159, 157-160. doi:https://doi.org/10.1016/j.econlet.2017.07.001

Arthur, D. (2016). Basic income: a radical idea enters the mainstream. Canberra: Parliamentary Library.

Arts, W., \& Gelissen, J. (2002). Three worlds of welfare capitalism or more? A state-of-theart report. Journal of European Social Policy, 12(2), 137-158. doi.org/10.1177/0952872002012002114 
Avi-Yonah, R. S. (2000). Globalization, tax competition, and the fiscal crisis of the welfare state. Harvard Law Review, 113(7), 1573-1676.

Baker, J. (2008). All things considered, should feminists embrace basic income? Basic Income Studies, 3(3), 1-8. https://doi.org/10.2202/1932-0183.1129

Baranowski, M. (2021). The Sharing Economy: Social Welfare in a Technologically Networked Economy. Bulletin of Science, Technology \& Society, 41(1), 20-30. https://doi.org/10.1177/02704676211010723

Baranowski, M., \& Jabkowski, P. (2019). Basic income attitudes and welfare regimes: A case study based on comparing survey results in selected european countries Studia Socjologiczne, 233(2), 1-24. https://doi.org/10.24425/sts.2019.126139

Basic Income Earth Network. (2017). Retrieved from http://basicincome.org/basic-income/

Bergmann, B. R. (2004). A swedish-style Welfare state or Basic Income: Which should have Priority? Politics \& Society, 32(1), 107-118. https://doi.org/10.1177/0032329203261101

Bergmann, B. R. (2008). Basic Income Grants or the Welfare State: Which Better Promotes Gender Equality? Basic Income Studies, 3(3), 1-7. https://doi.org/10.2202/19320183.1128

Byrne, B. M. (2016). Structural equation modeling with AMOS: Basic concepts, applications, and programming. London: Routledge.

Cardone, P. E. (2021). Public support for an EU-wide social benefit scheme: Evidence from round 8 of the European Social Survey (ESS). Rivista Italiana di Economia Demografia e Statistica, 75(1), 77-88.

Cerami, A. (2008). New social risks in Central and Eastern Europe: the need for a new empowering politics of the welfare state. Sociologický časopis/Czech Sociological Review, 44(06), 1089-1110.

Clark, C. M., \& Kavanagh, C. (1996). Basic income, inequality, and unemployment: rethinking the linkage between work and welfare. Journal of Economic Issues, 30(2), 399-406. https://doi.org/10.1080/00213624.1996.11505803

Cook, L. J. (2013). Postcommunist welfare states: Reform politics in Russia and Eastern Europe. Ithaca and London: Cornell University Press.

Cunliffe, J., \& Erreygers, G. (2001). The enigmatic legacy of Charles Fourier: Joseph Charlier and basic income. History of political economy, 33(3), 459-484. https://doi.org/10.1215/00182702-33-3-459

Dermont, C., \& Weisstanner, D. (2020). Automation and the future of the welfare state: basic income as a response to technological change? Political Research Exchange, 2(1), 1-11. https://doi.org/10.1080/2474736X.2020.1757387

Ehnts, D. H., \& Höfgen, M. (2019). The Job Guarantee: Full Employment, Price Stability and Social Progress. Society Register, 3(2), 49-65. https://doi.org/10.14746/sr.2019.3.2.04

Elgarte, J. M. (2008). Basic income and the gendered division of labour. Basic Income Studies, 3(3), 1-7. https://doi.org/10.2202/1932-0183.1136

ESS. (2016a). ESS Round 8 Module on Welfare Attitudes - Question Design Final Module in Template. London: ESS ERIC Headquarters c/o City University London.

ESS. (2016b). ESS Round 8 Source Questionnaire. London: ESS ERIC Headquarters c/o City University London.

Fitzgerald, R. (2015). Sailing in unchartered waters: structuring and documenting crossnational questionnaire design. GESIS Papers 2015/05, 1-24. Retrieved from https://nbnresolving.org/urn:nbn:de:0168-ssoar-462191

Fitzgerald, R., \& Jowell, R. (2010). Measurement equivalence in comparative surveys: the European Social Survey (ESS) — from design to implementation and beyond. In (pp. 485-495): John Wiley \& Sons, New York, NY, USA. 
Forget, E. L. (2012). Canada: The case for basic income. In M. C. Murray \& C. Pateman (Eds.), Basic Income Worldwide: Horizons of Reform (pp. 81-101). Basingstoke, New York: Palgrave Macmillan.

Friedman, M. (1962). Capitalism and Freedom. Chicago: University of Chicago Press.

Harrison, E., \& Rose, D. (2006). The european socio-economic classification (ESeC) user guide. Retrieved from Colchester, UK: https://www.iser.essex.ac.uk/files/esec/guide/docs/UserGuide.pdf

Haushofer, J., \& Shapiro, J. (2013). Household response to income changes: Evidence from an unconditional cash transfer program in Kenya. Massachusetts Institute of Technology, 24(5), 1-57.

Howard, M. W. (2005). Basic income, liberal neutrality, socialism, and work. Review of Social Economy, 63(4), 613-631. https://doi.org/10.1080/00346760500364775

Hughes, J. J. (2014). Are Technological Unemployment and a Basic Income Guarantee Inevitable or Desirable? Journal of Evolution and Technology, 24(1), 1-4.

Huppert, F. A., \& So, T. T. (2013). Flourishing across Europe: Application of a new conceptual framework for defining well-being. Social Indicators Research, 110(3), 837861. https://doi.org/10.1007/s11205-011-9966-7

Husson, M. (2006). Droit à l'emploi et réduction du temps de travail ou fin du travail et revenu universel? In M. Husson (Ed.), Travail, critique du travail émancipation (pp. 1131). Paris: Syllepse.

Husson, M. (2019). How Mainstream Economists Explain (or not) Unemployment? Society Register, 3(2), 21-37. https://doi.org/10.14746/sr.2019.3.2.02

Kaminska, O., \& Lynn, P. (2017). Survey-based cross-country comparisons where countries vary in sample design: issues and solutions. Journal of Official Statistics, 33(1), 123136. https://doi.org/10.1515/jos-2017-0007

Keating, M. (2009). Social citizenship, solidarity and welfare in regionalized and plurinational states. Citizenship studies, 13(5), 501-513. https://doi.org/10.1080/13621020903174654

Klein, E. (2018). Economic Rights and a Universal Basic Income. Griffith Journal of Law \& Human Dignity, 6(1), 102-115.

Lee, S. (2018). Attitudes toward universal basic income and welfare state in Europe: a research note. Basic Income Studies, 13(1), 1-9. https://doi.org/10.1515/bis-2018-0002

Lipsmeyer, C., \& Nordstrom, T. (2003). East versus West: comparing political attitudes and welfare preferences across European societies. Journal of European Public Policy, 10(3), 339-364. doi:https://doi.org/10.1080/1350176032000085342

Lucarelli, S., \& Fumagalli, A. (2008). Basic income and productivity in cognitive capitalism. $\begin{array}{llll}\text { Review of Social } & \text { Economy, }\end{array}$ doi:https://doi.org/10.1080/00346760802063000

Lynn, P., Häder, S., Gabler, S., \& Laaksonen, S. (2007). Methods for achieving equivalence of samples in cross-national surveys: the European social survey experience. Journal of Official Statistics, 23(1), 107.

Meuleman, B., van Oorschot, W., Gugushvili, D., Baute, S., Delespaul, S., Laenen, T., . . . Rossetti, F. (2018). The Past, Present and Future of European Welfare Attitudes: Topline Results from Round 8 of the European Social Survey. ESS Topline Series, (8), $1-16$.

Moran, M. (1988). Crises of the welfare state. British Journal of Political Science, 18(3), 397414. https://doi.org/10.1017/S0007123400005172

Murray, C. (2008). Guaranteed income as a replacement for the welfare state. Basic Income Studies, 3(2), 1-12. https://doi.org/10.2202/1932-0183.1115 
O'Reilley, J., Moyart, C., Nazio, T., \& Smith, M. (Eds.). (2017). Youth Employment: STYLE Handbook. Mountain View: CROME, Routledge.

OECD. (2017). Basic Income as a Policy Option: Can it Add Up? Policy Brief on the Future of Work, 1-8. Retrieved from https://www.oecd.org/social/Basic-Income-Policy-Option2017.pdf

Offe, C. (1984). Contradictions of the welfare state (J. Keane Ed.). Cambridge, Mass.: MIT Press.

Parolin, Z., \& Sioland, L. (2020). Support for a universal basic income: A demand-capacity paradox? Journal of European Social Policy, 30(1), 5-19. https://doi.org/10.1177/0958928719886525

Pateman, C. (2004). Democratizing citizenship: some advantages of a basic income. Politics \& Society, 32(1), 89-105. https://doi.org/10.1177/0032329203261100

Piachaud, D. (2018). Basic income: confusion, claims and choices. Journal of Poverty and Social Justice, 26(3), 299-314. https://doi.org/10.1332/175982718X15232797708173

Purdy, D. (1994). Citizenship, basic income and the state. New Left Review, 208, 30-48.

Rhodes, M. (2014). Southern European welfare states: Between crisis and reform (M. Rhodes Ed.). London and New York: Routledge.

Robeyns, I. (2001). Will a basic income do justice to women? Analyse \& Kritik, 23(1), 88105. https://doi.org/10.1515/auk-2001-0108

Roosma, F., \& van Oorschot, W. (2017). The social legitimacy of welfare states in European regions and countries: balancing between popular preferences and evaluations. In Handbook of European social policy (pp. 415-431). Cheltenham, UK and Northampton, MA, USA: Edward Elgar Publishing.

Roosma, F., \& van Oorschot, W. (2020). Public opinion on basic income: Mapping European support for a radical alternative for welfare provision. Journal of European Social Policy, 30(2), 190-205. https://doi.org/10.1177/0958928719882827

Roosma, F., van Oorschot, W., \& Gelissen, J. (2014). The preferred role and perceived performance of the welfare state: European welfare attitudes from a multidimensional perspective. Social science research, 44, 200-210. https://doi.org/10.1016/j.ssresearch.2013.12.005

Rose, D., \& Harrison, E. (2007). The European socio-economic classification: a new social class schema for comparative European research. European Societies, 9(3), 459-490. https://doi.org/10.1080/14616690701336518

Rossetti, F., Roosma, F., Laenen, T., \& Abts, K. (2020). An unconditional basic income? How Dutch citizens justify their opinions about a basic income and work conditionality. Journal of International and Comparative Social Policy, 36(3), 284-300. https://doi.org/10.1017/ics.2020.15

Schjoedt, R. (2016). India's basic income experiment. Pathway's Perspectives, 21, 1-10.

Shapiro, S., \& Shapiro, H. S. (1990). Between capitalism and democracy: Educational policy and the crisis of the welfare state. New York: Bergin \& Garvey.

Spicker, P. (2019). Basic Income, Human Rights and Equality. Retrieved from https://www.scottishinsight.ac.uk/Portals/80/SUIIProgrammes/Citizen\%27s\%20Basic\% 20Income/Exploring\%20Basic\%20Income\%20in\%20Scotland\%20$\%$ 20Human\%20Rights\%20and\%20Equality.pdf

Standing, G. (2013). India's experiment in basic income grants. Global dialogue, 3(5), 24-26.

Standing, G. (2017). Basic income: and how we can make it happen. London: Pelican.

Sutherland, L. (2018). Unpaid work, invaluable contribution: A feminist case for a Universal Basic Income. Women Talking Politics. A research magazine of the NZPSA, November, $39-41$. 
Svallfors, S. (2012). Welfare states and welfare attitudes. In S. Svallfors (Ed.), Contested welfare states: Welfare attitudes in Europe and beyond (pp. 1-24). Stanford: Stanford University Press.

Taylor-Gooby, P., \& Leruth, B. (Eds.). (2018). Attitudes, aspirations and welfare: Social policy directions in uncertain times. Cham: Palgrave Macmillan.

Toporowski, J. (2019). Financial Control and the Employer of Last Resort. Society Register, 3(2), 39-48. https://doi.org/10.14746/sr.2019.3.2.03

Van Parijs, P. (1992a). Basic income capitalism. Ethics, 102(3), 465-484. https://doi.org/10.1086/293420

Van Parijs, P. (1992b). Competing justifications of basic income. In P. Van Parijs (Ed.), Arguing for basic income: Ethical foundations for a radical reform (pp. 3-43). London: Verso.

Van Parijs, P. (2000). A basic income for all. Boston Review, 25(5), 4-8. Retrieved from http://bostonreview.net/archives/BR25.5/vanparijs.html

Van Parijs, P., \& Vanderborght, Y. (2017). Basic income: A radical proposal for a free society and a sane economy. Cambridge: Harvard University Press.

Vlandas, T. (2021). The political economy of individual-level support for the basic income in Europe. Journal of European Social Policy, 31(1), 62-77. https://doi.org/10.1177/0958928720923596

Widerquist, K., \& Sheahen, A. (2012). The United States: The Basic Income Guarantee-Past Experience, Current Proposals. In M. C. Murray \& C. Pateman (Eds.), Basic Income Worldwide: Horizons of Reform (pp. 11-32). Basingstoke, New York: Palgrave Macmillan.

Yang, A. (2018). The war on normal people: The truth about America's disappearing jobs and why universal basic income is our future. New York: Hachette Books.

Zelleke, A. (2005). Basic income in the United States: Redefining citizenship in the liberal state. Review of Social Economy, 63(4), 633-648. https://doi.org/10.1080/00346760500364866

Zelleke, A. (2008). Institutionalizing the universal caretaker through a basic income?. Basic Income Studies, 3(3), 1-9. https://doi.org/10.2202/1932-0183.1133 